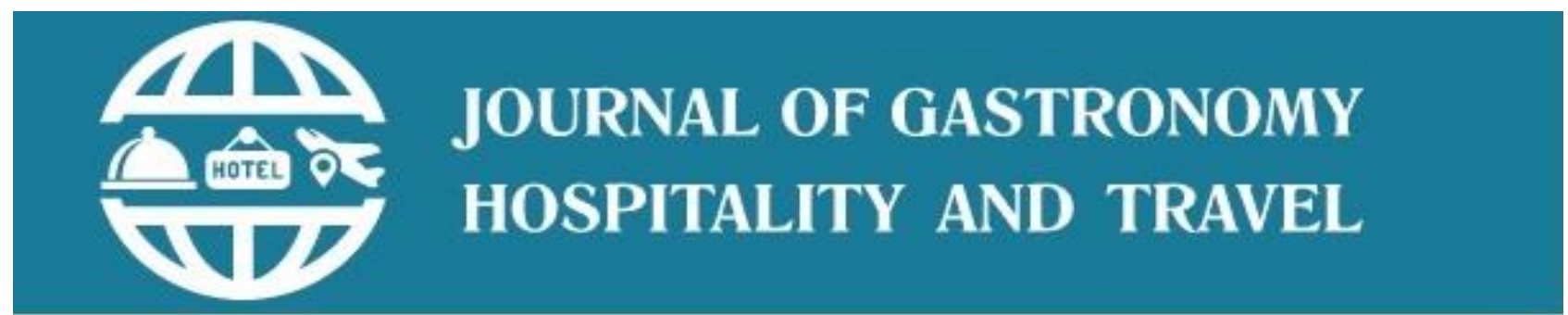

ISSN: 2619-9548

Journal homepage: www.joghat.org, http://dergipark.gov.tr/joghat

Journal of Gastronomy, Hospitality and Travel (JOGHAT)

2020 - Volume: 3 Number: 1

Page : $64-70$

Received: 08/05/2020

Revised:08/06/2020

Accepted: $12 / 06 / 2020$

\title{
Research Note \\ TALAIOTIC CULTURAL HERITAGE AS A TOURISM RESOURCE IN THE BALEARIC ISLANDS
}

\author{
Asier Baquero $^{1^{*}}$ (orcid.org/0000-0002-9500-9344) \\ Rafael Rivelles ${ }^{1}$ (orcid.org/0000-0001-8461-8040) \\ ${ }^{1}$ Faculty of Economics, Catholic University of Valencia, Valencia, Spain.
}

\begin{abstract}
Cultural heritage is an important resource for tourism. The ancient Talaiotic culture of the Balearic Islands, mainly found on the island of Minorca, represents an attraction for cultural tourism. This attraction can also improve the experience of tourists who visit the islands for leisure. The possibility of including the Talaiotic archaeologic sites of Minorca in the UNESCO World Heritage List could enhance tourism in Minorca. This research note presents a review and exploratory approach to the specific niche of cultural tourism in Spain. The purpose of the study is to deepen the relationship between tourism, cultural heritage and UNESCO.
\end{abstract}

Keywords: Talaiotic culture, Heritage, Cultural Tourism, Balearic Islands

\section{INTRODUCTION}

Heritage is a set of material or immaterial natural or cultural elements, either inherited from ancestors or created in the present, which allow people to recognise their identity and must be passed on to generations to come. Heritage must serve a social purpose; it must have an intention that serves the development of the group of people it belongs to. Heritage is a social, economic and cultural resource (Caravaca et al., 1997).

Hoteliers focus on leading their teams to provide customer satisfaction with the services offered by their hotels (Baquero, Delgado, Escortell and Sapena, 2019). It is thus reasonable to expect them to support the advancement of tourism activities and resources in the area around their destinations. Cultural heritage is a first-rate tourism resource. It is a key factor when designing most tourist itineraries. Heritage and tourism share a reciprocal relationship. Both need each other to survive. For example, it is unthinkable for a destination such as Spain to overlook its cultural heritage. Likewise, heritage also needs tourism to survive. Many palaces in Spain that now serve as museums would no longer make sense and would have fallen out of use if it had not been for the business brought by tourists. Thus, there appears to be a reciprocal relationship of mutual benefit.

Tourism has existed since people have been able to employ their free time by travelling to other locations. However, tourism has changed radically throughout history. Cuadrado and Lopez (2011) describe how tourism has been one of the drivers of Spanish economic growth in recent decades. There is little doubt

\footnotetext{
${ }^{1}$ To cite this document: Baquero, A. and Rivelles, R. (2020). Talaiotic Cultural Heritage as a Tourism Resource in the Balearic Islands, 3(1), 64-70. DOI: 10.33083/joghat.2020.31

Corresponding Author: asier.baquero@mail.ucv.es
} 
that it will continue to be so. To reach a state such as the one we find ourselves in nowadays, a series of crucial conditions are necessary. Examples include ease of movement, free time and the existence of a middle class with considerable purchasing power. All of these conditions did not exist in our Western society until the end of World War II. It was in the 1960s when the aforementioned conditions were truly met. Therefore, that decade marks the time when the so-called 'tourism boom' occurred, making tourism the mass phenomenon it is today.

Along with the emergence of tourism, the 1960s witnessed another vital factor in relation to cultural tourism: the democratisation of television. With the birth of television, there was an unprecedented shift in people's perception of reality. Reality became closer and could be present every day in people's very own living rooms. This change in the lives of those who only knew what they had seen in photographs or references was radical. It became possible to see things that had never been dreamt of before. The 'McDonaldisation' thesis can be applied to numerous industries, sometimes positively and other times negatively (Weaber, 2005).

Tourism and television thus bring us closer to realities that differ from our own. Both tourism and television allow us to observe a new spectacle, which is the reality of others. This reality is at first exotic, but little by little becomes more familiar.

Heritage, like television, is spectacular. Not only monuments, festivals and traditions, but also production processes and entire cultures have become spectacles or consumer goods through television or cultural tourism. All this can result in a profound transformation of heritage, which is seen most clearly in the tourism sector. With this new type of activity, the purpose of heritage as a memory is corrupted, and memory becomes disrupted. An image is promoted that, despite not being real, sells. We are no longer ourselves, but what others want us to be. Therefore, tourism, at least in part, has corrupted and continues to corrupt heritage. Heritage remains submissive to the needs of tourism and is thus distorted.

\section{TALAIOTIC CULTURE AND HERITAGE}

Talaiotic resources for tourism are a set of archaeological remains that are spread primarily throughout the island of Minorca, but that can also be found on the island of Mallorca, or Majorca (García, Fornés and Hoskin, 2000). These remains are former places of residence, religious sites and funeral enclosures of the Bronze Age and Iron Age. They represent a cultural tradition and reflect a unique type of construction, which is little known in mass tourism. There are several locations on the island of Minorca. Some are free to enter, and others charge a fee for visits.

The 'Talaiotic Minorca' ('Menorca Talayótica') project aims to achieve the inclusion of Talaiotic culture and heritage in the UNESCO World Heritage List. There are more than 30 locations on the island of Minorca (Talaiotic Minorca, 2020): Necrópolis de Cala Morell, Naveta des Tudons, Es Castellás des Caparrot de Forma, Ses Roques Llises, Trepucó, Torralba den Salord, Cova des Càrritx, Taula de Torrellisar, Hipogeu de Torre del Ram, Hipogeus de Biniai Nou, Monument de na Comerma de sa Garita, Naveta de Biniac Oriental, Navetes de Rafal Rubí, Necròpolis i Es Castellet de Calescoves, Poblat de Son Mercer de Baix, Poblat talaiòtic de Binissafúller, Poblat talaiòtic de Montefí, Sa Cudia Cremada, Poblat talaiòtic de Sa Torreta, Poblat talaiòtic de Sant Agustí, Poblat talaiòtic de Torrellafuda, Poblat talaiòtic de Torretrencada, Sala hipóstila des Galliner de Madona, So na Caçana, Sepulcre de Son Olivaret, Talaiot de Torelló, Talaiot de Trebalúger, Poblado de Cala Morell, Torre d'en Galmés, and Cornia Nou. 


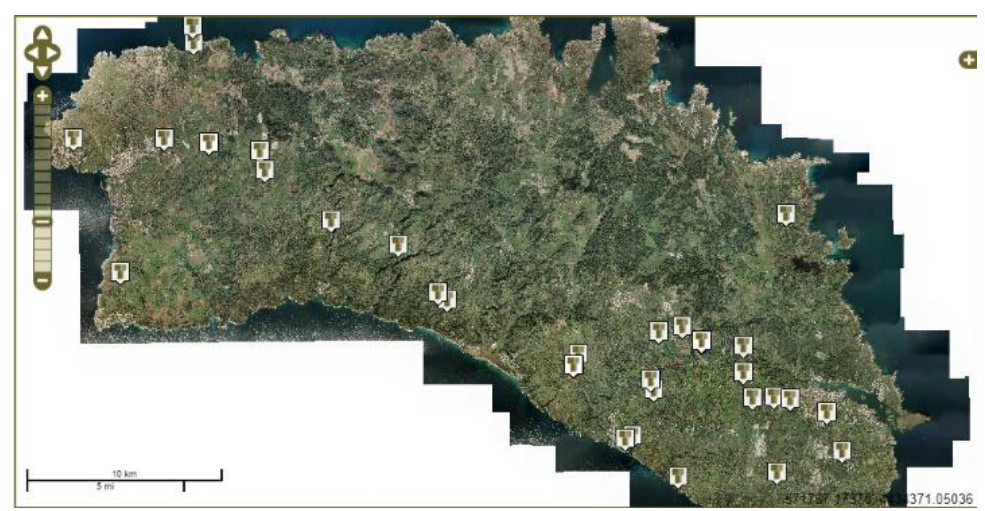

Figure 1. Location of sites on the island of Minorca (Talaiotic Minorca, 2020).

As a sample of what visitors can find, there are towns and necropolises built with large stones. These constructions appear majestically in the middle of landscapes. Examples are shown in Figures 2a and 2b.

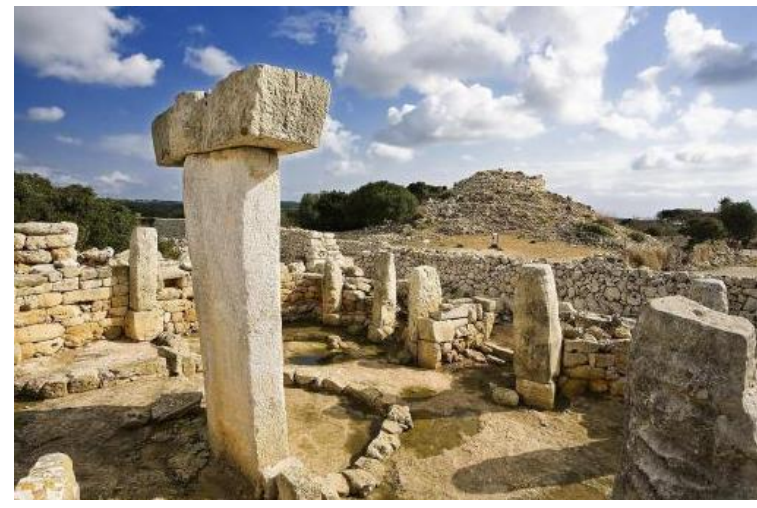

(a)

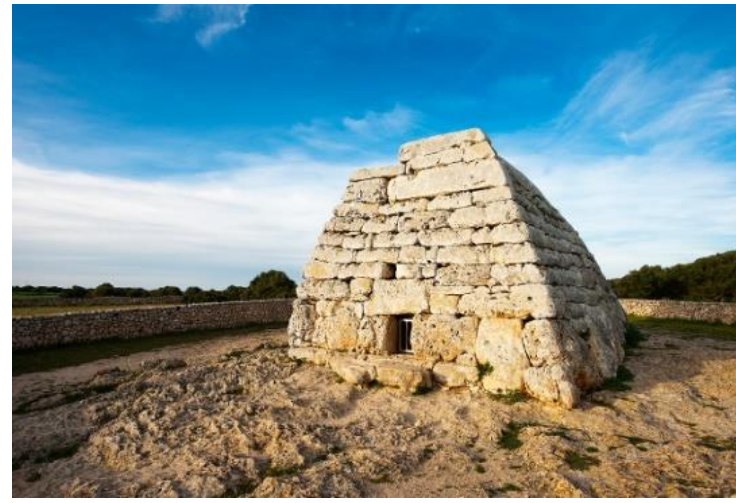

(b)

Figure 2. (a) Talaiotic settlement of Torralba den Salord (Menorca Info, 2020). (b) Naveta des Turons (Menorca Talayotica, 2020).

Studies have been carried out to determine exactly how these constructions were built and to explore the differences in their uses. These studies have only been able to confirm that they were fortified settlements, used either as homes or for funerals (Chapman and Grant, 1989).

\section{CULTURAL TOURISM}

Years ago, McIntosh and Goeldner (1986) defined cultural tourism as all aspects of a trip through which travellers learn about the history and heritage of a destination or about their contemporary way of life or thought. Right now, cultural tourism is difficult to define because of the complexity of the terms 'tourism' and 'culture', which comprise the concept. The literature offers many disparate definitions of cultural tourism. This concept is in a permanent process of construction, where the supply of resources and products based on monumental and material heritage are brought together, gradually expanding the overall meaning of the term. Cultural tourism also includes demand and its motivation. It is an increasingly broad and inclusive activity, where all its components intermingle and link with each other (Morere and Perello, 2013).

One of the first internationally accepted definitions of cultural tourism was the one adopted by ICOMOS (2020) following the Cultural Tourism Charter signed in Brussels in 1976: 'Cultural tourism is that form of tourism whose object is, among other aims, the discovery of monuments and sites. It exerts on these last a very positive effect insofar as it contributes - to satisfy its own ends - to their maintenance and protection. This form of tourism justifies in fact the efforts which said maintenance and protection demand of the human community because of the socio-cultural and economic benefits which they bestow on all the populations concerned.' 
However, in 1999, ICOMOS adopted a new Cultural Tourism Charter. Unlike the charter of 1976, this new charter is based on a broader definition of heritage, which also includes both tangible and intangible natural and cultural assets. According to Pulido, de la Calle and Velasco (2013), UNWTO and UNESCO proposed a broad and general definition of cultural tourism in 1985. This definition suggests that cultural tourism was already becoming a popular type of tourism because it states that ' $[\mathrm{a}] 11$ movements of persons might be included in the definition because they satisfy the human need for diversity, tending to raise the cultural level of the individual and giving rise to new knowledge, experience and encounters.'

UNWTO (2020) also proposed a stricter and narrower definition, which emphasises the motivation of tourists. According to this definition, cultural tourism refers to movements of people for essentially cultural motivations such as study tours, performing arts and cultural tours, travel to festivals and other cultural events, visits to sites and monuments, trips to study nature, folklore or art, as well as pilgrimages.

According to Tourspain (2020), cultural tourism is a trip with the specific purpose of knowing in depth a place, its people and customs, and in which the tourist is dedicated to visiting historical places, monuments and buildings, attending specific shows of music and art, and enjoying gastronomy.

Pulido, de la Calle and Velasco (2013) state that cultural tourism is the set of phenomena and relationships between tourism actors designed to promote activities that allow tourists to enjoy cultural, artistic and heritage events in a different environment from their everyday lives.

Prieto (2015) points out that despite abundant definitions and explanations, in general, cultural tourism is the form of tourism that generates aesthetic experiences (from architecture, buildings and other visual sources), intellectual experiences (from an increase in cultural and historical knowledge), emotional experiences (from curiosity, belief, affection, etc.) and experiences of authenticity or exclusivity. It follows that, despite not being a completely new phenomenon or a new type of tourism, cultural tourism has indeed changed in the extent of its consumption and the sorts of culture consumed by cultural tourists. It has also expanded massively in its range of activities to accommodate the new expectations and needs of tourist demand (consuming indigenous cuisine, enjoying popular festivals, and visiting theme parks, museums, monuments, etc.), whilst a novel facet is that it has become an object of consumption.

The great dynamism offered by cultural tourism, especially in recent times, forces us to redefine cultural resources in this form of tourism. Some of these cultural resources have already been established for many years, whilst others have been incorporated over the last few decades. This is especially true of those associated with the most modern examples of culture (music festivals, contemporary art, audiovisual creations, multimedia, comics, street art, etc.). The constant readjustment of tourist activity, fundamentally from the point of view of demand, requires the frequent updating of the map of cultural resources to glimpse the type of settings that are framed within cultural tourism (Prieto, 2015).

According to Prieto (2015) and UNWTO (2020) cultural tourism includes a huge variety of cultural resources of very different types. These can be summarised as follows: visits to places and knowledge of material assets (world heritage, monuments, etc.), contact with expressions of intangible heritage (religious events, performing arts, etc.) and participation in events or practices related to modern contemporary culture (thematic installations, street art, etc.).

\section{THE ROLE OF UNESCO IN CULTURAL AND HERITAGE TOURISM}

UNESCO was inspired by the principles of the Universal Declaration of Human Rights. Since its creation in 1946 in Paris, UNESCO has worked to defend cultural heritage as the UN organisation tasked with promoting education, science and culture. Its cultural heritage division, which belongs to the UNESCO culture sector, is in charge of looking after cultural assets and museums, and it handles the corresponding international campaigns. It also implements operational projects in cooperation with the World Heritage Centre, across a network of organisations.

The 1972 World Heritage Convention, ratified by 190 countries, establishes that certain places on Earth with 'exceptional universal value' belong to the common heritage of humanity. In other words, all states are part of an international community united in the joint mission to identify, protect and care for the most important examples of natural and cultural heritage on our planet, regardless of where they are located. This 
convention is unique in that it links the concept of nature conservation with the preservation of cultural sites. Thus, the assets included in the World Heritage List are divided into three categories: cultural assets, natural assets and mixed assets. To be included in the World Heritage List, the assets must have exceptional universal value and must meet at least one of the 10 selection criteria. Talaiotic Minorca meets two of them (Menorca Talayotica, 2020):

Criterion 3: 'to bear a unique or at least exceptional, testimony to a cultural tradition or a civilisation which is living or which has disappeared'. Talaiotic Minorca falls chronologically between the Late Bronze Age (2500-2000 BC) and the Iron Age (650-400 BC). The excellent state of preservation and diversity of its sites makes Talaiotic Minorca unique and of exceptional value when compared with other prehistoric cultures.

Criterion 4: 'to be an outstanding example of a type of building or architectural or technological ensemble or landscape which illustrates (a) significant stage(s) in human history'. The first settlers of Minorca left their mark on the landscape with their diverse constructions. These are found all over the island and span a long period, from the Bronze Age to the Iron Age. Their use extends to the Roman Empire and the Islamic rule on the island.

The candidacy for World Heritage of Talaiotic Minorca has led to a range of actions aimed at achieving the greatest possible participation of citizens, owners, municipalities and especially ASHOME, the Hotel Association of Minorca (Gornes, Gual and Rojas, 2015). In fact, ASHOME has actively participated as a member of different working groups to support the candidacy for World Heritage of Talaiotic Minorca. ASHOME has contributed by providing the hoteliers' broad experience in direct relation to the island's tourists and their comments, preferences and tastes.

It might also have been expected that the application would have had some impact on the conservation and tourist development of the sites. However, according to several researchers, it seems not to be the case. There is still much work to be done in terms of the protection and maintenance of the sites. According to the study by Adie, Hall, and Prayag (2017) on three places declared World Heritage Sites, this status has a placebo effect: it is a cultural brand or label that evokes the idea of high quality. Yet this placebo effect does not act directly on tourists, but rather on politicians and local agents who think that the title itself will cause a notable increase in tourism. However, it must be accompanied by other actions to promote the destination. After analysing 178 papers, Ruiz and Pulido (2015) likewise concluded that more than $20 \%$ of the authors observed negative cases of tourism as a result of obtaining UNESCO status, whilst only $18 \%$ of authors see UNESCO status as positive for tourism.

Cultural tourism focuses on archaeological sites that are closely related to the environment. However, these sites are also fragile, can become over exploited and may foment the destruction of ecosystems, as has been observed in certain cases in the Mexican Caribbean (Cordoba and Garcia, 2003)

\section{CONCLUSIONS}

People like to travel and enjoy tourism for different reasons. It could mean travelling to a Slovenian city for its gastronomy (Fuste-Forne, 2019), or it may involve travelling for cultural reasons, as discussed in this paper. Experts and lovers of cultural tourism will travel anywhere, anytime. However, for the general public, knowing that a destination has been listed on the UNESCO World Heritage List is a major attraction.

Despite different opinions on whether the fact that a tourist resource benefits overall from being included in the UNESCO World Heritage List, it would seem to be beneficial for tourism in Minorca. It could help differentiate this 'sun-and-sand' tourist destination from similar destinations in the Mediterranean that lack such a rich cultural offering. It could also extend the tourism season by actively promoting this cultural attraction at the beginning and the end of the season.

Regarding the tourist adequacy and accessibility, it is important to bear in mind that the island of Minorca is highly subject to seasonality, with the season restricted to summer months. Additionally, adapting visits to these places for people with disabilities would be an improvement that should be considered in the future. 


\section{REFERENCES}

Adie, B. A., Hall, C. M., \& Prayag, G. (2017). World Heritage as a placebo brand: a comparative analysis of three sites and marketing implications. Journal of Sustainable Tourism. 399-415. doi.org/10.1080/09669582.2017.1359277

Baquero, A., Delgado, B., Escortell, R., \& Sapena, J. (2019). The influence of transformational and authentic leadership on the satisfaction of hotel customers in the Canary Islands. Tourism and Hospitality Research, 1-14. doi.org/10.1177/1467358419891458

Caravaca, I., Colorado, D., Fernandez, V., Paneque, P., Puente, R., \& Romero, C. (1997). El patrimonio cultural como factor de desarrollo en Andalucía. Boletín del Instituto Andaluz del Patrimonio Histórico, 20, 87-97.

Chapman, R., \& Grant, A. (1989). The talayotic monuments of Mallorca: formation processes and function. Oxford Journal of Archaelogy. doi.org/10.1111/j.1468-0092.1989.tb00191.x

Cordoba, J., \& Garcia, A. (2003). Tourism, globalization and the environment in the Mexican Caribbean Coast. Investigaciones geograficas, 117-136.

Cuadrado, J.R., \& Lopez J.M. (2011). El turismo: un sector clave en la economía española. Papeles de economia espanola, 128.

Fuste-Forne, F. (2019). Flavors of Ljublajana culinary scene. Journal of Gastronomy, Hospitality and Travel, (2) $108-111$.

García, J., Fornes, J., \& Hoskin, M. (2000). Orientations of the Talayotic Sanctuaries of Mallorca. Journal for the History of Astronomy, 31(25), 58-64. doi.org/10.1177/002182860003102505

Gornes, S., Gual, J. M., \& Rojas, A. (2015). Procesos de participación social en la candidatura de Menorca Talayotica a la nominacion como patrimonio mundial. In Personas y comunidades: Actas del Segundo Congreso Internacional de Buenas Practicas en Patrimonio Mundial. Universidad Complutense de Madrid, Servicio de Publicaciones, Madrid, pp. 627-637.

ICOMOS (2020). Associated to UNESCO. Retrieved 17 April 2020, from https://www.icomos.es

McIntosh, R. W. \& Goeldner, C. R. (1986). Tourism: Principles, practices, philosophies. New York: Wiley. Menorca Info (2019). La "Menorca Talayotica" no optará al título mundial al menos hasta 2022. Retrieved 17 Abril 2020, from

https://www.menorca.info/menorca/local/2019/04/06/653869/menorca-talayotica-optara-titulo-mundialmenos-hasta-2022.html

Menorca Talayotica (2020). Retrieved 17 April 2020, from http://www.menorcatalayotica.info/ 
Morere, N., \& Perello, S. (2013). Turismo cultural. Patrimonio, Museos y Empleabilidad, Fundacion EOI, Madrid. Retrieved 17 April 2020 from https://www.eoi.es/es/eventos/12056/turismo-culturalpatrimonio-museos-y-empleabilidad

Prieto, J.J. (2015). Turismo cultural: el caso español. International Journal of Scientific Management and Tourism, (2), 95-114.

Pulido, J.I., de la Calle, M. \& Velasco (2013). Turismo cultural. Madrid: Ed. Síntesis.

Ruiz, A., \& Pulido, J.I. (2015). El impacto del turismo en los Sitios Patrimonio de la Humanidad. Una revision de las publicaciones científicas de la base de datos Scopus. Pasos online, 13 (5), 1247-1264.

Sitges, J. (2009). Poblado talayótico de s'Illot. Retrieved 17 April 2020, from https://www.ultimahora.es/mallorca/ocio/actividades-familiares/poblado-talayotico-de-s-illot.html

Tourspain (2020). Retrieved 17 April 2020 from https://www.tourspain.es

Weaber, A. (2005). The Mcdonaldization tesis and cruise tourism. Annals of Tourism Research, 32 (2), 346366.

UNWTO (2020). Tourism and culture. Retrieved 17 April 2020, from https://www.unwto.org/es/tourismand-culture 